Journal of Language Teaching and Learning, Linguistics and Literature

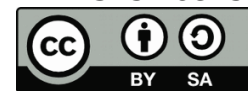

Issued by English study program of IAIN Palopo

ISSN 2338-4778 (Print)

ISSN 2548-4192 (Online)

Volume 6, Number 1, June 2018

pp. $44-55$

\title{
The Correlational Study Between Students Interest and The
}

\section{Students Reading Comprehension}

\author{
Reski Yusrini Islamiah Yunus \\ musliadi_uncp@yahoo.com \\ Cokroaminoto Palopo University
}

Received : 11 Mei 2018; Accepted : 28 Mei 2018

URL : $\quad$ http://ejournal.iainpalopo.ac.id/index.php/ideas

\begin{abstract}
The objectives of the study are to find out significant correlation between reading interest through the students' reading comprehension. In this research, the researcher used quantitative method by Pearson correlation product moment. There are four variables in this research. Students' interest as prediction variable and Reading comprehension as criterion variable, the technique of collecting data was by using a questionnaire and test. The questionnaire consists of 20 items and 46 items of reading comprehension. The object of study is 30 students from class $D$ at the third semester. After getting the score of the students' interest and reading comprehension, the data were statistically computed to find out the correlation between those variables. From the calculation by using product moment formula, it was found out that the mean scores of the student's interest 75.53. The mean of the scores of the students' reading comprehension is 5.53. The result of applying the variable $r_{x 1 y}$ (ro) distribution shows that the coefficient correlation between students interest and reading comprehension is 0.919 or $91.9 \%$ means that there was very strong correlation. The degree of significance $5 \%$ is 0,000 . It means $p$ is smaller than $0.05(0.05<0.000)$. So, alternative hypothesis $(\mathrm{Ha})$ is accepted and null hypothesis $(\mathrm{Ho})$ is rejected. The conclusion of this research is there is a significant correlation between students 'interest and their reading comprehension.
\end{abstract}

Keywords: Students Interest; Reading Comprehension. 


\section{Introduction}

Reading is one of language skills that will reach in learning English. Reading as a part of learning English still have some problems. One of the problem students' face nowadays is not their inability to read but, their lack of interest, stimulus or enthusiasm of reading.

Interest is one of the learner's internal factors. It may have a significant influence on the student's reading ability. One of them is interest. According to Iskandarwassid \& Sunendar (2008) "Reading is determined by interest" (p. 246). In this case, the students can be successful to comprehend in reading English text if their teacher gives an appropriate interest based on students' characteristics. This argument is similar with the opinion of Guthrie, Laurel, Stephen \& Nichole (2007, p. 310) study (as citied in Saddhono \& Slamet, 2012, p. 91) they stated that reading comprehension would be more effectively if it is being supported by interest. In this case, from these views, it can be concluded that reading comprehension and interest have strong relationship because reading comprehension will be supported by interest. According to the primarily observation, the researcher found that most of the students have interest in reading is very less, it showed that when they did the assignment which is related to reading, consist of several simple passage. They prefer to directly answer the passage without having to read it. Those factors cannot be ignored in teaching reading comprehension.

Nowadays the educators might accept the importance of interest. The students' interest toward reading is a central factor affecting reading comprehend. Interest toward reading is an important educational outcome. Student's interest is a feeling that accompanies or causes special attention to reading. The students will read actively if they were motivated in reading. Because it can make them consider reading activity as a habitual activity for them. Interest is very influence for reading activeness. Because of reading for and achievement in reading were also dependent upon the student's interest in reading, and poor reading or reading failure may be caused by lack of interest. To achieve in reading, the students must want to learn.

Talking about interest, that interest consists of intrinsic and extrinsic interest. Sardiman (2010) stated the intrinsic interest comes from inside factor while the extrinsic interest comes from outside factor. For example, students want to achieve the goals caused by self-driven themselves called intrinsic interest. If the students want to achieve the goals because of other person called extrinsic interest (p. 89). In addition, McClelland (1960) (as cited Siagian (2004, pp. 167- 171) classified intrinsic and extrinsic interest into three indicators, they are: achievement, affiliation, and power. The both of interests are very important to give encouragement to the students in doing activity especially to make student successful to comprehend the content of text. 
The Correlational Study between Students Interest and the Students Reading Comprehension

According those problem, the researcher attempt in conducting a research about "The Correlational Study between Students Interest and Their Reading Comprehension."

Haris as cited by Olson and Dillner (1982:5) defines reading as a process of meaning elaboration or thinking in relation to written symbols. This definition presupposes that two aspects are essential to reading process, word recognition and comprehension. He also adds that reading may range from the visual perception of word forms and their meanings to perception and comprehension of written messages in a manner parallel to that of the corresponding spoken messages.

To sum up, reading is not merely a process of reading words by words of a printed material but it is also a collaboration of a thinking process, a recollection of the past experience and the capacity of acquired language faculty to interpret the researcher's intention. In addition, reading can also be said as a process of matching information since in reading activity, the reader matches his information that he has already had with the printed material in order to get the researcher messages. Reading can simply be viewed as the process of the readers' thinking in relation to written symbols to get comprehension; it is also an interactive process between the reader's prior knowledge and what the writer writes.

Reading and comprehension are two terms which are always interrelated. In reading, there will be a process to understand and comprehend a text; hence comprehension. On the other hand, comprehending a text entails reading.

According to Bond, Pinker and Wasson (1979:3) in our world, reading more will provide more information and it makes our knowledge become increasingly great in numbers. Clark and Sandra (in Simanjuntak, 1988:15) define reading as an active cognitive process of increasing with print and monitor comprehension to establish meaning. Kennedy (1982:5) has an argument that reading can be defined as the ability of an individual to recognize a visual form; associate the form with a sound and or meaning acquired in the cover and on the part of experience, understands, and interprets its meaning.

From the statement above, reading is a process that is done and also is used by the readers to get the message. Finocchiaro (1974:77) says: "Reading is getting meaning from the printed or written material." According to Recheck Lost and Learner (1983:7), in general, in reading the ability to recognize word and to comprehend literal meanings are important components. The reading levels for the students are immediate, the definition of reading includes a deeper understanding of passages.

In order to comprehend reading selection thoroughly a person must be able 
to use the information to make inferences and read critically to understand the figurative, determine the author's purpose evaluate the ideas presented, and apply the ideas to actual situations. All of these skills involve thinking process (Burns, 1984:10-11).

Reading without comprehension is not a real reading. It is reading when a reader reads a printed page by recognizing and also comprehending the meaning of the text. Obviously, a real reading is reading with understanding or comprehending. Either reading is done to get information or merely to get pleasure; a reader has to comprehend what he reads. Accordingly, the real purpose of reading is comprehension.

Indeed, those who have achieved the highest level of reading comprehension will get a better progress in reading any kinds of text. Nevertheless, it is important to note that the success of reading comprehension does not merely depend on one's ability to read but it also depends on other factors.

Interest can be developed through interest. A wise teacher would motivate his or her students before starting his/her lesson in class. Nasution (1977) says that interest is all resources to encourage a person to do something. The researcher believe that to get the students interested in reading, interest is needed. Reading in the limited sense or in the broad sense is interesting. Interest motivates one to read and put effort because the reading selection is interesting. Usually a person knows more about a topic in which she/he has interest that makes reading comprehension easier.

Therefore it is necessary to present some definitions or theories of interest as proposed by psychologists in order to have a clear description about what interest is. Benjamin S. Bloom (1971:16-17) defines interest as behaviorally in terms of whether or not the individual would voluntarily engage in additional learning tasks and they are free to make such a choice. Further he explains that interest can be defined more subjectively in terms of the individual's liking, enthusiasm, preference, and desire.

Reading interest is a feeling that accompanies or causes special attention to reading. The students will read actively if they are interest in reading. Because it can make them consider reading activity as a habitual activity for them. Interest is very influence for reading activeness. Because of reading for and achievement in reading are also dependent upon the student's interestal reading, and poor reading or reading failure may be caused by lack of interest. To achieve in reading, the students must want to learn.

According to Ortlieb (2010:5) interests are positive attitudes of attraction toward objects or events. They are learned responses which predispose the organism to certain lines of activity and which facilitate attention. Interest is the set of attending, the tendency to give selective attention to something. Interests arise through the interaction of basic needs and the means used to satisfy them. The child who is interested in reading is usually the child for whom 
The Correlational Study between Students Interest and the Students Reading Comprehension

reading satisfies the basic needs of personal adequacy or self-esteem, esteem of others, curiosity, or success.

Purves and Beach, as quoted by Alexander (1988:407) classify the factors influencing interest in reading in two main headings.

1) Personal

The factors included in this category are age, gender, intelligence, concentration, emotion in reading, reading ability, psychological needs and attitude.

2) Institutional

The factors included in this category are availability of books, attempt to read, the use of time, socioeconomic status and ethnic background, peers, parents, teacher's influences, TV and movies. Harris and Sipay (1980:257) also give two additional factors influencing interest in reading, i.e. the illustration and difficulty level of materials.

Futhermore, Bond Guy.L., et al. (1984:382) state the factors that have influence on interest in reading are availability of material, attitude towards reading, the competition for leisure time between reading and leisure time activities, guidance towards higher quality of reading, and reading ability.

a. The Types of reading interest

According to Dawson in Sutini (2010) there are two types of reading interest such as:

1) Spontaneous reading interest is interest that grows spontaneously from within one's self without being influenced by external factors.

2) Systematic reading interest is an interest that arises as a result of the influence and activities of the systematic or patterned included in teaching and learning activities, whether at school or outside school. Interest can be equated with patterned external factors, which are the concrete are the result of extrinsic interest. Thus interest may be inhibited, influenced, even was spread out.

\section{Method}

The research conducted by using a correlation method to describe about the correlation between student's interest and their reading comprehension. The method of this research was correlational design. It correlated to students' interest and their reading comprehension ability. It was descriptive quantitative research which want to describe the correlation between students' interest and their reading comprehension ability.

The population of this research was the third semester students of UNCP (Universitas Cokroaminoto Palopo) in academic year 2016/2017. Sample was a part of the population which is investigated (Arikunto, 2006: 131). The 
researcher used the method of population research, if the research subject less than 100 is better to take all of it. Thus, it was regarded as a population research. If the research subject more than 100, the researcher can takes 10$15 \%$ or $20-25 \%$ from the population (Arikunto, 2006:134). Because of the population of this research are more than 100 , so the researcher takes $20 \%$ of the population to represent total of 30 students. The random sampling chosen because the researcher took sampling with "mixing" the subject of population research and all subjects were have the same characteristic. Thereby, the researcher gave equal right to choose the subjects of study as the sample.

There were two kinds of instruments that used in this research. They were questionnaire and test.

\section{Questionnaire for Student's Interest}

Questionnaire is used to measure students' interest in reading text. It was adapted from reading interest inventories choice by Ryan Finley and Dave Goldbreg (1991) and partly from AJ Bastian (2013). The time allotment for answering the questionnaire was ninety minutes including the preparation and explanation.

As its format, the instrument consists of three parts:

1. Introduction, which contains the aim of distributing the questionnaire;

2. Respondent's identity

3. Content, which consists of 8 statements that reflect the components of students' interest in reading text (8 items).

The answer in each item will be transform into quantitative data. The data is analyzed by using arithmetic means. Each item is followed by the scale called Likert Scale. Tuckman, (1972:179) states that a Likert Scale is a five points scale in which the interval between each point on the scale is assumed to be equal. It is actually called an equal appearing interval scale. This scale is used to register the extent of agreement or disagreement with a particular statement of an attitude, belief, or judgment. An example: 1. Strongly Agree, 2. Agree, 3.Undecided, 4. Disagree, 5. Strongly Disagree.

The respondents should choose one of the five options to show their attitude toward the item offered to them. The scoring of the questionnaire is determined by summing up the value assigned to individual response. To score the rate, each item is credited $5,4,3,2$ or 1 from favorable to unfavorable answer. Conversely, the response options are credited $1,2,3,4$, or 5 from unfavorable to favorable answer.

\section{Positive Statements}

Scores
Negative Statements 
The Correlational Study between Students Interest and the Students Reading Comprehension

\begin{tabular}{|c|c|c|}
\hline Strongly Agree & 5 & Strongly Disagree \\
\hline Agree & 4 & Disagree \\
\hline Undecided & 3 & Undecided \\
\hline Disagree & 2 & Agree \\
\hline Strongly Disagree & 1 & Strongly Agree \\
\hline
\end{tabular}

Source: (Arikunto, 2006:229)

Table. 3.1 The score of questionnaire

To measure the reliability of the instruments of the questionnaire in this study, the researcher applied the formula Alpha Cronbach. Before the questionnaire was used as the instrument to collect the data, it was tried out to know its validity and reliability.

2. Test

The research instrument played an important role to collect data. The instrument used in this research is an objective test, and the researcher used one type of objective test, which is multiple-choice type. Multiple-choice type can be scored objectively and can measure learning out come directly.

In this research, the test consist of 46 items with five alternatives for reading comprehension test. The alternatives included one correct answer and three wrong answers. There were some passages and from each passage the researcher made a question on reading comprehension including question of vocabulary, main idea, detail, not detail, and inference. The score of each item is one, so highest total score is forty. The time allotment of those test was ninety minutes including the preparation and explanation of doing the test. The result gains from the questionnaire and the test analyzed through statistical package social science (IBM SPSS) version 20.

\section{A. Procedure of Data Collection}

The procedure of data collection is the following sessions:

\section{Questionnaire}

The researcher distributed the questionnaire to the students. It aimed to get students' response to reflect the students' interest. First of all, the researcher gave a brief explanation about the purpose of the questionnaire distribution and on how to fill them. The researcher talked to the students that there is not right and wrong answer for the questionnaires. After that, the 
researcher asked them to choose one of the five Likert-scales based on their own themselves that they did in learning English. At last, after filling in the questionnaires, the students would submit the questionnaires to the researcher. The answer sheet checked and count to get the students score.

2. Test

The researcher distributed the test to the students in the day after distributing the questionnaires to the researcher. Firstly, the researcher gave a brief explanation about the purpose of the test distribution and how to fill it. They were inform that this test aims to measure students' reading comprehension ability.

\section{B. Technique of Data Analysis}

The analysis used in this study are descriptive statistical analysis and inferential statistical analysis. Descriptive statistical analysis means that the data were analyze descriptively. Presenting table, percentage and frequency is done to support the analysis of the three variables (Moore, 1987). Inferential statistical analysis means that analysis which is used to investigate the hypothesis. Before that, researcher should do the normality testing and homogenates' data of three variables.

After that, to determine whether or not there is relationship between students' interest in reading text, word knowledge and their reading comprehension. Firstly, the researchers correlated the score of the student's interest using Pearson's Product Moment Correlation analysis. While to know the relationship between students' interest $(\mathrm{X})$ and their comprehension $(\mathrm{Y})$ the researchers analyzed the relationship of the variables in their linearity. Then, continue to process the data by using regression process using regression formula of correlation as follows:

$Y=a+b 1 X 1, Y=a+b 2 X 2$, and $Y=a+b 3 X 3$

Where, $Y=$ Score of criterion/ dependent variable

$\mathrm{X}=$ Score of predictor variable/Independent variables

$b=$ Coefficient predictor

$\mathrm{a}=\mathrm{a}$ constant

After that, the researcher investigates the relationship between variables using the Product Moment Correlation techniques. Finally, the researcher could see the relation or contribution of independent to dependent variable ( $R$ Square). Those calculations are conducted by using IBM SPSS version 20 for windows. 
The Correlational Study between Students Interest and the Students Reading Comprehension

\section{Results}

a. Rate percentage of students' score on pretest

Table 1. The rate percentage of pretest score of the pre-experimental group

\begin{tabular}{llccc}
\hline \multirow{2}{*}{ No } & \multirow{2}{*}{ Classification } & \multirow{2}{*}{ Score } & \multicolumn{2}{c}{ Pre experiment } \\
\cline { 4 - 5 } & & F & $\%$ \\
\hline 1. & Excellent & 96 to 100 & 0 & 0 \\
2. & Very Good & 86 to 95 & 0 & 0 \\
3. & Good & 76 to 85 & 0 & 0 \\
4. & Fairly Good & 66 to 75 & 1 & $5 \%$ \\
5. & Fair & 56 to 65 & 2 & $10 \%$ \\
6. & Poor & 36 to 55 & 17 & $85 \%$ \\
7. & Very poor & 00 to 35 & 0 & 0 \\
\hline & $\quad$ & 20 & $100 \%$ \\
\hline
\end{tabular}

b. Rate percentage of students' score on posttest

Table 2. The rate percentage of posttest score of the pre-experimental group

\begin{tabular}{|c|c|c|c|c|}
\hline \multirow{2}{*}{ No } & \multirow{2}{*}{ Classification } & \multirow{2}{*}{ Score } & \multicolumn{2}{|c|}{ Pre experiment } \\
\hline & & & $\mathrm{F}$ & $\%$ \\
\hline 1. & Excellent & 96 to 100 & 0 & 0 \\
\hline 2. & Very Good & 86 to 95 & 0 & 0 \\
\hline 3. & Good & 76 to 85 & 6 & $30 \%$ \\
\hline 4. & Fairly Good & 66 to 75 & 4 & $20 \%$ \\
\hline 5. & Fair & 56 to 65 & 10 & $50 \%$ \\
\hline 6. & Poor & 36 to 55 & 0 & 0 \\
\hline 7. & Very poor & 00 to 35 & 0 & 0 \\
\hline & Total & & 20 & 100 \\
\hline
\end{tabular}

c. The mean score and standard deviation of the students' pretest

After calculating the result of the students' pretest, the mean score and standard deviation are presented in following table:

Table 3. The mean score and standard deviation of the students' pretest

\begin{tabular}{ccc}
\hline Group & Mean Score & Standard Deviation \\
\hline Pre experimental & 50.10 & 5.821 \\
\hline
\end{tabular}


IDEAS, Vol. 6, No. 1, June 2018

d. The mean score and standard deviation of the students' posttest

Having calculated the students' pretest, the next test to be analyzed is posttest. The following is the table that describes the mean score and standard deviation of the students' posttest.

Table 4. The mean score and standard deviation of the students' posttest

\begin{tabular}{ccc}
\hline Group & Mean Score & Standard Deviation \\
\hline Pre experimental & 68.00 & 5.947 \\
\hline
\end{tabular}

e. Response of the Students

In this part, the researcher distributed the same question to the students of SMP Negeri 1 Palopo about their response of using simon says game in teaching vocabulary specified for the second (VIIIA) year students.

The question is: Senangkah kalian belajar kosakata bahasa inggris dengan menggunakan simon says game?

These are the transcription of students' response about simon says game:

\begin{tabular}{|c|l|l|}
\hline No & Students' Code Name & \multicolumn{1}{|c|}{ Students' Response } \\
\hline 1. & CLA & Senang \\
\hline 2. & EPI & Senang \\
\hline 3. & DSI & Senang \\
\hline 4. & AVR & Senang \\
\hline 5. & ASN & Sangat menyenangkan \\
\hline 6. & DNI & Senang sekali \\
\hline 7. & SRN & Senang \\
\hline 8. & GGN & Sangat senang \\
\hline 9. & ITN & Senang \\
\hline 10. & NTL & Sangat senang \\
\hline 11. & KME & Amat senang \\
\hline 12. & DWN & Senang sekali \\
\hline 13. & NLA & Senang \\
\hline 14. & NEL & Senang \\
\hline 15. & AJN & Sangat senang \\
\hline 16. & INL & Senang \\
\hline 17 & APS & Senang \\
\hline 18 & HBP & Senang \\
\hline 19. & EMI & Senang \\
\hline 20. & FDO & Senang \\
\hline & & \\
\hline
\end{tabular}

The description of the data collects through vocabulary test as explained 
The Correlational Study between Students Interest and the Students Reading Comprehension

in the previous section shows that the students' ability improves significantly. It is supported by the result of the students' pre-test and post-test. The data in previous section shows that the use of simon says game is effective in improving students' vocabulary. It is supported by the mean score of post-test (68.00) which is categorized as fairly good and the mean score of pre-test (50.10) which is categorized as poor.

The data indicates that the use of simon says game effective to improve the students' vocabulary achievement.

Based on the result of T-Test, the researcher finds that the p-value of posttest is lower than $\alpha(0.00<0.05)$. The t-test value of post-test is remarked significant difference. It indicates that the alternative hypothesis $\left(\mathrm{H}_{1}\right)$ is accepted and of course, the null hypothesis $\left(\mathrm{H}_{0}\right)$ is rejected. It is proved that the use of simon says game in improving students' vocabulary is effective.

Supardi (2011) states that simon says game is the game in which one person gives commands, the others have to carry them out, the trick is that they must only obey commands that are preceded by "simon says". To focus attention on its use for vocabulary teaching, one technique migbt be to teach the parts of the face or action verb : touch your eyebrows, touch your cheeks, simon says touch your nose. The teacher introduces the vocabulary needed, and the students carry out the actions in due course the students may take over the ordering role. They are reacting to the new vocabulary with physical movements, they are doing something that will help them to remember. By using simon says game the students can be required to make active, meaningful use of new vocabulary immediately.

Another fact shows that the use of simon says game gives better effect to the students, it is proved by the students' response, all the students gave positive response. This is implies that the use of simon says game in learning vocabulary is a good technique because the students feel enjoyable and easier to understand the material.

\section{Conclusion}

The data shows that the use of simon says game in improving students' vocabulary is effective. The students' score in post-test is improved and it can be seen from the result of post-test to prove it. The use of simon says game improves students' achievement in vocabulary, it is shown by the students' result in posttest. Mean score of students' posttest is higher than pretest $(68.00$ $>50.10$ ) so, it is significant difference. The probability value is smaller than $\alpha$ $(0.00<0.05)$, it indicates that the alternative hypothesis $\left(H_{1}\right)$ is accepted and the null hypothesis $\left(\mathrm{H}_{0}\right)$ is rejected. It means that students' vocabulary can improve by using simon says game at the second year students of SMP Negeri 
IDEAS, Vol. 6, No. 1, June 2018

ISSN 2338-4778 (Print) ISSN 2548-4192 (Online)

1 Palopo and the students also gave positive responses in learning vocabulary by using simon says game.

Teacher should give the exact technique in teaching vocabulary. The students should be given materials by using "simon says game in improving their vocabulary". The teacher and the next researcher should be more creative in giving the best technique in teaching English, not only in vocabulary component but also another component in English. Due to its limitation, the present research is just held six times for treatments, so it is not maximized. Therefore, it is suggested that there should be a further research with more exercises on component to be improved.

\section{References}

Dictionary.reference.com/browse/simon+say. Accesed on 2016-03-21.

Hornby, A.S. (1974). Oxford Advanced Learner's Dictionary of Current English. Tokyo: London Oxford University Press.

Hornby, (1995). Oxford Advanced Learner's dictionary of Current English. London : Oxford university Press.

Long, Michael H and Richard Jack C. (1987). Methodology in TESOL : A Book of Reading. Boston, Massachusetts: Newbury House Publishers.

Richards and Willy A Renandya. (2002). Methodology in Language Teaching : An Anthology of Current Practice. Cambridge: Cambridge University Press.

Supardi. (2011). Teaching Vocabulary by Using Simon Says Games at the First Year Students of SMP Negeri 1 Baebunta. Unpublished Thesis of STAIN Palopo.

Webster, Mariam. (1990). Webster's ninth New Collegist Dictionary. Massachusetts : Meriam - webster Inc. Publisher. www.definitions.net/definition/Simon 